\title{
ACCEPTANCE OF OWN CORPOREALITY IN THE CONTEXT OF THE DEVELOPMENT OF MARITAL RELATIONSHIPS: CONTRADICTIONS AND THEIR RESOLUTION
}

UDC: 159.923 .2 [316.362.1-058.833-055.1-055.2]

\section{Bevz Halyna}

Phd (Doctor of Psychology), Professor, Head of Communication Psychology Lab, Institute for Social and Political Psychology of National Academy of Educational Sciences of Ukraine, Kyiv (Ukraina)

ORCID ID: https://orcid.org/0000-0003-2487-5429

\section{SUMMARY}

The results of the study relate to the gender differences in the attitude of the married couples to their own body. It is stated that the attitude towards one's own body is a situational characteristic that is variable throughout life. Positive attitude to own body acts as a condition of social activity, development of interests and satisfaction with married life. Critical environment enhances motivation for changes in one's own body, which is more typical of women under the age of 30 without children. Manifestations of sociability, as well as the support of a partner and the request for his/her support, can help to withstand the devastating tendencies directed at the attitude towards own body. The revealed factors of developing a positive attitude towards one's own body (support, development of interests and cognitive sphere) appear more promising for the formation of indicators of the balance of marital life than the use of critical attitude to the body with increased motivation for its changes.

Key words: family, marriage, gender relationship, physical culture.

Introduction. Biopsychosocial approach is increasingly triggering in the psychological science the research on acquisition of the characteristics of balance in the functioning of different systems of deployment of human life (including corporeal). The achievement of such a balance is especially important for the development of marital and family relationships: a sense of happiness, well-being, mutual understanding, acceptance and consent reduces energy expenditure of a person, strengthening the vital capacity of each member of the family group. At the same time, physical existence of a person, social representations of his or her corporeality, as well as physical sensitivity in the context of the development of marital life, is not sufficiently represented in scientific sources. In view of the transformational changes in modern society (development of informational 
society, globalization tendencies and growth of the share of mediated communication in on-line mode), as well as decrease in physical activity and motivation for the development of physical culture, the importance of the study of this direction of everyday marital life is especially intensified.

Analysis of recent research. Questions of corporeality, as a psychophysiological and physical state of the individual, are the subject of interdisciplinary knowledge and need integration in their study. In the scientific debate, «corporeality» appears in two dimensions: as a sociocultural phenomenon and as a natural basis of the mental, which demands appropriate attention and relevant support. In psychology, the category of corporeality is not a separate category of study and is explored mainly in the context of such concepts as: the phenomenon of femininity / masculinity, sexuality and gender psychology (T. Govorun, \& O. Kikinezhdi, 2004); on issues of psychophysical development

(K. Dondar, 2013; V. Koriahin, O. Blavt, O. Bezghrebelna, \& T. Liudovik, 2012), the development of «physical-Self» in the process of personal formation (O. Gumeniuk, 2004; T. Khomulenko, 2016) as well as the concept of bodily identity (V. Nikitin, 1998). On the one hand, issues of the corporeality are considered in the context of the psychosomatic concepts of diseases as well as the phenomena of deprivation as a decrease in the overall vital resilience of the body (V. Nikolaeva, 2009). On the other hand, they deal with the issues of developing a healthy lifestyle (K. Bondar, 2013; L. Korobka, 2012). In the area of marital life the category of corporeality mainly relates to the psychophysical level of marital compatibility and to the issues of disorders in the sexual sphere of private life (Chitsazzadeh, Zahrakar, \& Sanai, 2017; Stroud, Durbin, Saigal, \& Knobloch-Fedders, 2010). It is also described in the author's concept of V. Tatenko (2014) as the result of experiencing the contradictions between the physical characteristics and the ambitions towards one's own body and the growing demands from the socio-cultural environment.V. Tatenko (2014, 95-112) highlights such directions of its analysis as «corporeal for oneself», «corporeal for me» and «corporeal for others». The first points to physical characteristics of own body as the medical-health parameters, the second fixes corporeality as a way to achieve life goals; the third is socially determined and mediated by cultural stereotypes. It is worth noticing the notion of «psychosomatic competence», which T. Khomulenko and V. Kramchenkova (2016) consider as a cognitive component of the «physical Self», which causes the acceptance of own body and serves the integration of bodily experience and holistic selfregulation of the body. Also, the studies on evaluating of physical characteristics of one's own body in the context of different types of «eating behaviour» in women with manifestations of addiction, as well as differentiation of evaluation of the share of body in development of marital rela- 
tions, seem to be important (Vik. Mykhailov, Vol. Mykhailov, \& Yu. Korostylova, 2013). It turns out that the intimate side of the life of the couple, which involves physical and mental closeness, is still not sufficiently studied by scientists, specifically for the category of «corporeality».

Purpose and tasks. Basing on presented above positions of particular studies on the gender aspects of the psychology of corporeality, we sought in our work to reveal the peculiarities of the manifestation of acceptance of one's own body by men and women in the context of their marital life. The purpose of the research was to study the attitude to their own body of the representatives of married couples in the categories "acceptance-rejection" and its presentation in marital interaction through the concept of "criticism of the appearance from the partner's side" and "motivation to change one's own body".

Research methods. A questionnaire of 15 questions was developed in order to reveal a body perception and the wish/motivation to change one's body as a sign of one's own dissatisfaction. To measure the indicator «unfavorable judgement of the respondent's appearance by his/ her partner» as a sign of partner's dissatisfaction, a questionnaire of 5 questions was developed. Additional tools were also used to determine the strength of ties in a married couple manifested by common values and interests, mutual support, as well as seclusion as an indicator of alienation and detachment in relationships. The developed toolkit was shaped into a single diagnostic unit including the following items: a questionnaire to identify common interests of married couples (a total of 33 items) based on the translated Oregon Avocational Interest Scales by Lewis Goldberg; Method of «Network of Support Relationships» (W. Furman, \& D. Buhrmester, 2010); the Schwartz's Value Orientations Test adjusted by V. Karandashev (2004) and UCLA method (D. Russell, L. Peplau, M. Ferguson in the version of I. Ishmukhametov, 2006; L. Goldberg, 2010). The survey was conducted by using the questionnaires (direct and on-line). The survey respondents were residents of different regions of Ukraine with the prevalence of Kyiv city and Kiev oblast.

The study sample was made of 300 individuals (men and women). The respondents age ranged from 19 to 75 years old, whereas the length of marital life ranged from 0.5 to 55 years. Most of the respondents are married and have children. Only a small part of the sample (10.4\%) is represented by couples cohabiting without marriage registration - these are mostly young people under the age of 30 . The below Diagram 1 shows that the distribution of the length of marital life of the sample respondents can be regarded as uniform $\left(\chi^{2}=4.25 ; p=0.236\right)$, as well as the distribution of respondents according to the number of children in their families $\left(\chi^{2}=1.83 ; \mathrm{p}=\right.$ $0.404)$.

The sample respondents are also charac- 


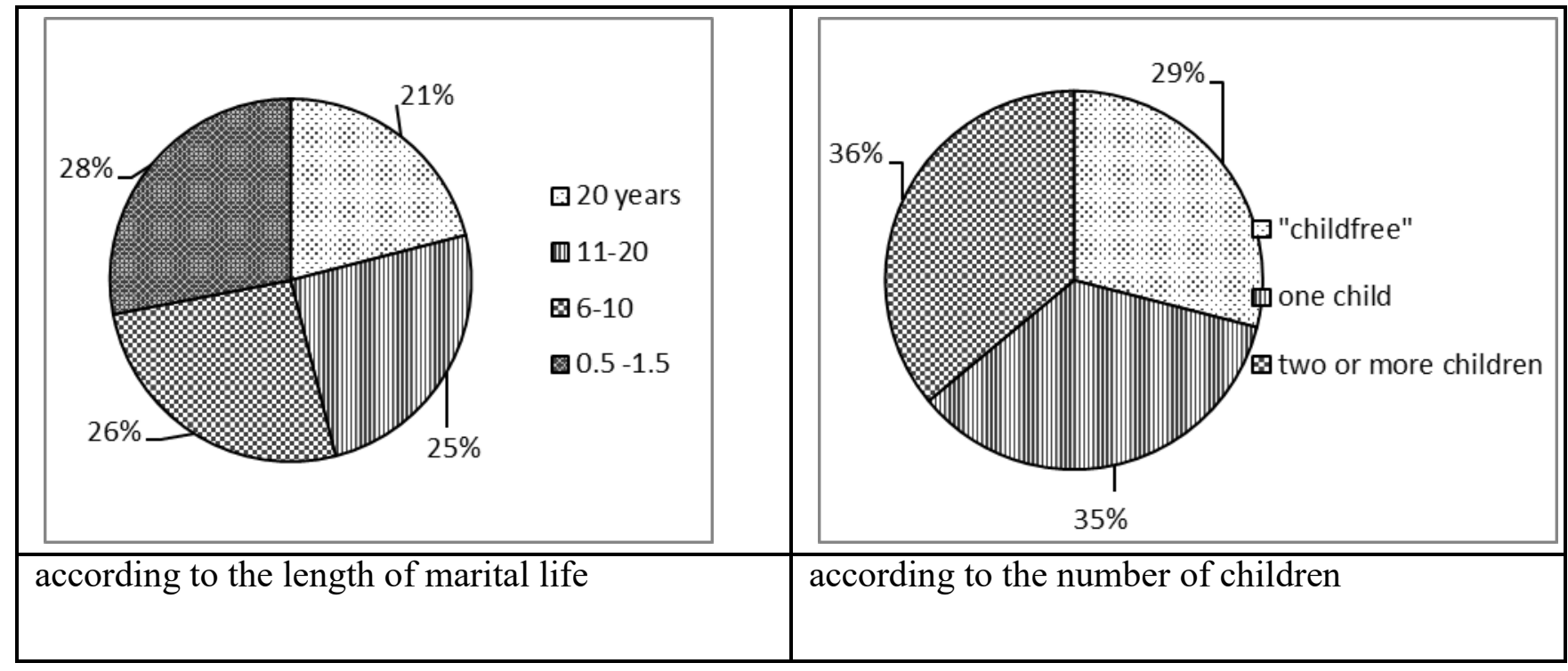

Diagram. 1. Distribution of the sample by family status characteristics

terized as self-sufficient and able to provide for their own life. The studied families have a predominantly average income level (enough money for necessities) and above average income level (enough money for food, clothes, and durable goods, but not enough money to make expensive purchases (apartment, vehicle). The aggregate percentage of such families is $84.8 \%$. It should be noted that the precondition for participation in the survey was the respondents' interest in building up their own family relationships, which is also an additional characteristic of the sample.

To process the received data, the mathematical statistics methods, in particular descrip- tive and inductive, as well as correlation analysis were used. To compare the two unrelated samples, the Mann-Whitney U-criterion was used, whereas the Kruskal-Wallis H-criterion was applied to compare the data from various groups.

Discussion. The analysis of the empirical data showed that, in general, the studied respondents group showed a positive perception of their body, as well as a strong desire to maintain and improve it. In the context of these results, it is entirely anticipated that the unfavorable judgement of one's appearance by his/her partner did not receive high values (Table 1).

Table 1

Mean values of body perception indicators

\begin{tabular}{|l|l|l|l|}
\hline Indicators & $\begin{array}{l}\text { Mean } \\
\text { values }\end{array}$ & $\begin{array}{l}\text { Standard } \\
\text { deviation }\end{array}$ & S.E.M. (95\%) \\
\hline Positive own body perception & 70.82 & 16.17 & 2 \\
\hline Motivation to change the body & 72.05 & 19.6 & 2.43 \\
\hline Unfavorable judgement of appearance & 36.42 & 15.06 & 1.87 \\
\hline
\end{tabular}


The survey has statistically proved the lack of gender differences with regard to positive body perception among men and women. It has been also found out that the «positive body perception» indicator has no statistically significant links with the financial and family status indicators, as well as the length of joint habitation (including the length of marriage). Instead, the motivation to change one's own body is still higher among women (the trend reducing with aging), whereas men (42.06) are more likely to experience unfavorable judgement of their appearance by others (34.83; $U=4467.0 ; p \leq$ 0.056). Table 2 shows that the motivation to change their own body is more peculiar to women, which is related to age and childbirth processes. Actually it is women who tend to change their physical shape and, therefore, need to revise their attitude towards those changes. Thus, it is highly likely that external evaluations of the altered body shapes by spouses will affect the process of reconsidering perceptions by wives of their new body appearances.

As expected, the positive perception of one's own body negatively correlates with the motivation for body change $(\mathrm{r}=-0.65 ; \mathrm{p}<0.001)$, as well as with the indicator «unfavorable judgement of one's appearance by the partner» $(\mathrm{r}=$ $0.3 ; \mathrm{p}<0.001)$. The last two indicators are positively interrelated $(r=0.34 ; p<0.001)$. The data obtained emphasizes the importance of external influences in the own body perception and acquiring positive attitude towards it.

It has been statistically proved that a positive perception of one's own body is an important factor in generating overall satisfaction with family life. The more positive the perception, the higher the overall level of satisfaction with family life ( $\mathrm{r}=0.28 ; \mathrm{p}<0.001)$. Currently, all functional family life areas (leisure, joint entertainment activities, sexual and psychological relations, child-rearing practices, comfort and cleanliness at home, overall financial welfare of the family) are directly related to the positive body perception $(\mathrm{r}=$ from 0.17 to $0.26 ; \mathrm{p}<0.01)$. At the same time, the positive body perception is most strongly related to the home cleanliness and comfort $(r=0.26 ; p<0.001)$, the financial welfare of the family $(r=0.23 ; p<0.001)$ and the cared-for children $(r=0.22 ; p<0.01)$. According-

Table 2

Motivation for body change according to the spouses' social status

\begin{tabular}{|l|c|c|c|c|c|c|}
\hline \multirow{3}{*}{ By gender } & Female & Male & & & $\mathrm{U}$ & $\mathrm{p}$ \\
\cline { 2 - 7 } & $\mathbf{7 3 . 4 4}$ & 67.15 & & & 6387.0 & 0.030 \\
\hline \multirow{3}{*}{ By number of children } & Childfree & One child & $\begin{array}{c}\text { Two or } \\
\text { more chil- } \\
\text { dren }\end{array}$ & & $\mathrm{H}$ & $\mathrm{p}$ \\
\cline { 2 - 7 } & $\mathbf{7 6 . 8 9}$ & 72.88 & 67.58 & & 8.03 & 0.018 \\
\hline & 30 (or under) years old & $\begin{array}{c}31-40 \text { years } \\
\text { old }\end{array}$ & $\begin{array}{c}41-55 \\
\text { years old }\end{array}$ & $\begin{array}{c}\text { over) years } \\
\text { old }\end{array}$ & $\mathrm{H}$ & $\mathrm{p}$ \\
\cline { 2 - 8 } & $\mathbf{7 7 . 6 8}$ & 71.46 & 67.88 & 65.60 & 9.32 & 0.025 \\
\hline
\end{tabular}


ly, "criticism of appearance on the part of the partner" has negative correlations with the indicators of satisfaction with family life in the above mentioned spheres. Only the sphere of leisure allows certain expansion of the range of communication, even with negative criticism of appearance, as indicated by the absence of statistically significant connection between these indicators.

In addition, we have identified a number of significant correlation links of a positive body perception with interests. The positive body perception serves for the development of 12 types of interests $(36 \%)$ out of the 33 ones available in the questionnaire. These include positive correlations with food interests $(r=0.23 ; p<0.001)$, ecology $(\mathrm{r}=0.21 ; \mathrm{p}<0.001)$, romance $(\mathrm{r}=0.21 ; \mathrm{p}<0.01)$, technology $(\mathrm{r}=0.23 ; \mathrm{p}<0.001)$, physical exercise $(\mathrm{r}=0.22 ; \mathrm{p}<0.001)$, entertainment $(\mathrm{r}=0.17 ; \mathrm{p}$ $<0.01)$, education $(\mathrm{r}=0.18 ; \mathrm{p}<0.01)$, and travel $(\mathrm{r}$ $=0.16 ; \mathrm{p}<0.01)$. Weaker yet significant correlations are also observed in relation to artistic impression, fashion, shopping, and tourism ( $\mathrm{r}$ from ( 0.13 to $(0.16 ; \mathrm{p}<0.05)$. The above-mentioned correlations make it possible to state that a positive perception of one's own body enhances the quality of both family and social life by focusing the person's interests on mastering the living environment and strengthening social contacts, supporting the life ecology and the desire to make it attractive and full of prospects. At the same time, the indicators of expected and provided support from the partner (support network) did not receive significant correlations with the positive body perception indicator. In this regard, we can suggest that the positive body perception has an earlier term of formation in a human ontogeny and the partner's support is the subject of adult relationships that are estabilshed at a mature age. Instead, the unfavorable judgement by the partner has a significant impact on the destruction of a positive perception of one's own body. The unfavorable judgement of one's appearance by the partner has very clear and expected correlations: positive with proneness to conflict $(r=0.29 ; p$ $<0.001)$, antagonism $(\mathrm{r}=0.32 ; \mathrm{p}<0.001)$ and criticism, and negative with seeking partner's support $(r=-0.16 ; p<0.01)$, desire to support the partner $(\mathrm{r}=-0.17 ; \mathrm{p}<0.01)$, amicability $(\mathrm{r}=$ $0.22 ; \mathrm{p}<0.001)$. The unfavorable judgement of appearance by the partner is positively related to the interests of seclusion $(r=0.15 ; p<0.05)$ and spending time with computer $(r=0.16 ; p<0.05)$. The higher the level of unfavorable judgement of the partner's appearance, the less is the interest evinced in the household ( $\mathrm{r}=-0.18 ; \mathrm{p}<0.01)$, artistic impression $(\mathrm{r}=-0.13 ; \mathrm{p}<0.05)$ and cognition $(\mathrm{r}=0.18 ; \mathrm{p}<0.01)$. The indicator "unfavorable judgement of appearance by the partner» is inversely related not only to the satisfaction with family life $(r=-0,27 ; p<0,001)$, but also with each of its components ( $\mathrm{r}$ from $-0,16$ to $-0,27 ; \mathrm{p}<0.05)$. Only the leisure activity, while preserving the above-described tendencies, did not receive a statistically significant relation to the indicator «unfavorable judgement of appearance by the partner «. The negative relations to 
the indicators «psychological relationships» $(\mathrm{r}=$ $0,27 ; \mathrm{p}<0,001)$ and «home cleanliness and comfort» $(r=-0,25 ; p<0,001)$ are the strongest. Simultaneously, the survey has identified an inverse link to reducing the unfavorable judgement impact, which results from the partner's support $(r=$ $-0.17 ; \mathrm{p}<0.005)$ and from seeking partner's support $(\mathrm{r}=-0.16 ; \mathrm{p}<0.005)$. This restoring process can particularly derive from the manifestations of amicability in marital interaction that are completely opposite to the category of «unfavorable judgement by the partner" ( $r=-0,22 ; \mathrm{p}<0,001)$.

Thus, we can state that the unfavorable judgement of appearance by the partner has a devastating effect on the positive body perception, including the reduction of the person's prosociality.

Balanced against this process, there is also an «amicability» indicator and a positive support network from the partner. The contradictions revealed empirically confirm the already described antonymic nature of the body existence in a culture, thereby limiting its discursive cognition (K. Bondar, 2013). Also, the study provides an opportunity to put forward a hypothesis about the culture of marital communication, which manifests itself in their role activity, particularly in relation to sexual relations, organization of cultural leisure as well as entertainment (Table 3 ).

Absence of significant correlations between the parameters "Support from the partner" and "search for support from the partner" by the test "Network of support relationships" and listed areas of marriage confirms this hypothesis. All of these spheres of life appeared to be

Table 3

Correlations of support categories by the «Network of Support Relationships» test

\begin{tabular}{|l|l|l|l|l|l|l|l|l|}
\hline \multicolumn{1}{|c|}{ Categories } & $\begin{array}{l}\text { Support } \\
\text { from } \\
\text { the } \\
\text { partner }\end{array}$ & Conflict & $\begin{array}{l}\text { Search for } \\
\text { support } \\
\text { from the } \\
\text { partner }\end{array}$ & $\begin{array}{l}\text { Antagonis } \\
\text { m }\end{array}$ & $\begin{array}{l}\text { Support } \\
\text { of the } \\
\text { partner }\end{array}$ & Criticism & $\begin{array}{l}\text { Search for } \\
\text { support of } \\
\text { the partner }\end{array}$ & Sociability \\
\hline $\begin{array}{l}\text { Satisfaction with } \\
\text { family life }\end{array}$ & $\begin{array}{l}0.48 \\
* * *\end{array}$ & $\begin{array}{l}-0.45 \\
* * *\end{array}$ & $0.4 * * *$ & $-0.49 * * *$ & $0.43 * * *$ & $-0.43 * * *$ & $0.41 * * *$ & $0.5 * * *$ \\
\hline Solitude & -0.08 & $\mathbf{0 . 1 7} * *$ & $\mathbf{- 0 . 1 6 * *}$ & $\mathbf{0 . 1 5 *}$ & $\mathbf{- 0 . 1 5 *}$ & $\mathbf{0 . 1 4} *$ & $\mathbf{- 0 . 1 7 * *}$ & $\mathbf{- 0 . 1 2 *}$ \\
\hline Culture & 0.03 & 0.06 & 0.1 & 0.11 & 0.04 & 0.03 & -0.08 & 0.02 \\
\hline Entertainment & -0.05 & 0.06 & -0.03 & $\mathbf{0 . 1 4} *$ & -0.06 & 0.06 & $\mathbf{- 0 . 1 8 * *}$ & $\mathbf{- 0 . 1 2 *}$ \\
\hline Sexual relations & -0.08 & 0.05 & 0.01 & 0.05 & 0.02 & 0.1 & -0.08 & -0.08 \\
\hline $\begin{array}{l}\text { Communication } \\
\text { in the network }\end{array}$ & 0.01 & 0.1 & 0.1 & $\mathbf{0 . 1 3} *$ & 0.05 & $\mathbf{0 . 1 3} *$ & -0.09 & 0.02 \\
\hline $\begin{array}{l}\text { Positive attitude } \\
\text { towards own } \\
\text { body }\end{array}$ & & & & & & & & \\
\hline $\begin{array}{l}\text { Motivation for } \\
\text { changes in the } \\
\text { body }\end{array}$ & 0.09 & -0.05 & 0.05 & $\mathbf{- 0 . 1 4 *}$ & 0.06 & $\mathbf{- 0 . 1 9} * * *$ & 0.03 & 0.11 \\
\hline $\begin{array}{l}\text { Criticism of } \\
\text { appearance }\end{array}$ & $* 0.05$ & $\mathbf{0 . 1 6} * *$ & 0.03 & $0.24 * * *$ & 0.01 & & $\mathbf{0 . 2 3} * * *$ & 0.01 \\
\hline
\end{tabular}

Note: Significance level: $* * * \leq 0,001 ; * * \leq 0,01 ; * \leq 0,05$. 
beyond the support network, and, moreover, some of them are activated in a situation of growing antagonism, criticism, reducing sociability and even with the growing need for support from the partner. The latter shows that the signal of need for support is not always understood by the couple, and under certain circumstances may be ignored, thus reducing confidence in marital interaction and weakening emotional connections. Instead, the results of the survey convince at the level of statistical significance that mutual support is still a guarantee of positive development of relationships, giving respondents a sense of satisfaction with family life, while conflict and antagonistic relationships lower this indicator (see Table 3). In confirmation of the above, it should be noted that in situations of conflict ( $\mathrm{r}$ $=0,17 ; \mathrm{p}<0,0)$, antagonism $(\mathrm{r}=0,15 ; \mathrm{p}<0,01)$ and criticism $(\mathrm{r}=0,14 ; \mathrm{p}<0,05)$ actualization of the solitude behavior is observed. At the same time, in case of an active search for support by the partner $(\mathrm{r}=-0,16 ; \mathrm{p}<0.01)$ and from the partner $(\mathrm{r}=-0,17 ; \mathrm{p}<0.01)$, the need for such solitude behavior is significantly reduced. It should be borne in mind that actual support from the partner was statistically insignificant in choosing the behavior of solitude (see Table 3). Thus, the contradictions found in the correlation analysis are as follows: role activity in the sphere of entertainment increases in the situation of antagonism $(r=0,14 ; p<0,05)$, as well as in diminishing partners' manifestations of sociability $(r=$ $-0,12 ; \mathrm{p}<0.05)$ and partner's activity for receiv- ing support $(\mathrm{r}=-0,18 ; \mathrm{p}<0.01)$. In this case, the interest in contacts in the network is accompanied by increase in antagonism and criticism ( $\mathrm{r}$ $=0,13 ; p<0,05)$. The described correlations suggest us that the partners lack the ability to build relationships based on support (ability to provide and ask for it) while giving preferences to strategies for switching from benevolent to malicious relationships and vice versa. Manifestations of antagonism, criticism and conflict can be a trigger in such situations. The absence of significant positive correlations between acts of support and role appearances in the sphere of culture and sexual relations reaffirms the above (see Table 3 ).

Regarding the indicator «desire to change one's own body», the statistically significant relations with the indicator «overall dissatisfaction with the family life» $(r=-0.13 ; \mathrm{p}<0.05)$ has been identified without significant relations to any of its components. At the same time, reducing the number of interests (from 12 to 3) takes place, while the relations structure undergoes changes, thus enhancing the tendencies of reducing the desire to cognize the social environment and direct contacts. The invert relations have also been found between the motivation for body change, on one hand, and the interests evinced in gardening and planting $(\mathrm{r}=-0.16 ; \mathrm{p}<0.05)$, religion $(\mathrm{r}=$ $-0.13 ; \mathrm{p}<0.05)$ and technology $(\mathrm{r}=-0.13 ; \mathrm{p}$ $<0.05$ ), on the other. At the same time, positive correlations are observed with the interests for computer $(\mathrm{r}=0.2 ; \mathrm{p}<0.01)$ and communication in the network $(r=0.14 ; p<0.05)$. In general, the 
motivation for changing the body has positive relations with the conflicts $(r=0.16 ; p<0.01)$, antagonism $(r=0.24 ; \mathrm{p}<0.001)$, and criticism ( $\mathrm{r}$ $=0.23 ; \mathrm{p}<0.001$ ), thus revealing this type of motivation as reactive, that is provoked by dissatisfaction of the partner as a significant person.

Conclusions. Thus, by confirming the antonymic nature of corporeality in the context of marital life, the survey has statistically proved that the positive perception of one's own body acts as a precondition for positive perception of the world, prosocial activity and satisfaction with family life, both in general and in each area. The positive perception of own body turned out to be independent of the presence/absence of support from the spouse; however it is rather sensitive in situations of unfavorable judgements of appearance by the partner towards its destruction. The confrontational, antagonistic and criticizing environment enhances the motivation to change one's own body, which is more peculiar to women by virtue of their natural age (childbirth) changes in the physical body. Manifestations of amicability, as well as support from the partner and request for his/her support, have an opposite value in terms of the indicator "unfavorable judgement of appearance by the partner" and can help resist destructive trends in the situations of reconsidering attitudes towards one's own body. The latter can be useful in planning counseling and psychotherapeutic practice with married couples encountering truobles when building up their relationships, including the intimacy life.
The study of the nature of corporeality as a systemic formation, which increases the ability of a person to function in a balanced way within the living environment, seems to have potential. The possibility for making such statements will serve a purpose of reviewing the medical concept of illnesses and enhancing scientific knowledge targeted at mastering life cycles focusing on selfregulation.

\section{References :}

Bondar, K. V. (2013). Teoretiko-metodologichni pidhodi do rozglyadu fenomenu tilesnosti. Naukoviy visnik Mikolayivskogo derzhavnogo unIversitetu imeni V. O. Suhomlinskogo, 2 (10), 42-45.

Govorun, T., Kikinezhdi, O. (1999). Stat ta seksualnist: psihologichniy rakurs. Ternopil: Bogdan.

Govorun, T., Kikinezhdi, O. (2004). Genderna psihologiya. Kiyiv: Akademiya.

Gumenyuk, O. E. (2004). Psihologiya Ya-kontseptsiyi. Ternopil: Ekonomichna dumka.

Ishmuhametov, I. N. (2006). Psihometricheskie harakteristiki shkalyi odinochestva ucla (versiya 3): izuchenie studentov vuza. Computer Model lingand New Technologies, 10 (3), 89-95

Karandashev, V. N. (2004). Metodika Sh. Shvartsa dlya izucheniya tsennostey lichnosti. Sankt-Peterburg: RECH'.

Korobka, L. M. (2012). Psihologichne zdorov'ya lyudini v konteksti zdorovogo sposobu zhittya. Osvita regIonu: politologiya, psihologiya, komunikatsiyi, 2, 332-337.

KoryagIn, V. M., Blavt, O.Z., Bezgrebelna, O. P., Lyudovik T. V. (2012). Ozdorovcha fIzichna kultura v 
zhiti doroslogo naselennya. Teoriya ta metodika fIzichnogo vihovannya, 5, 8-11

Mihaylov, VIk., Mihaylov, Vol., Korostilova,Yu. (2013). Optimalni pokazniki normi masi tlla u zhinok i cholovikiv. Suchasniy sotsiokulturniy prostir, Materiali X Mizhnarodnoyi naukovo-praktichnoyi Internet konferentsiyi, 2, 65-73.

Nikitin, V. N. (1998). Psihologiya telesnogo soznaniya. Moskva: Aleyteya.

Nikolaeva, V. V.[Red.]. (2009). Psihosomatika. Telesnost i kultura. Moskva.

Tatenko, V. (2014). PsihologIya intimnogo zhittya. Kirovograd: Imeks-LTD.

Homulenko, T. B., Kramchenkova, V. O. (2016). Metodika proektivnoyi diagnostiki tilesnogo «Ya». Naukoviy visnik Hersonskogo derzhavnogo universitetu. 5, $39-45$.

Bahareh Chitsazzadeh Alaf, kianoush zahrakar, Bagher Sanai. (2017). Effect of practical application of intimate relationship skills program in marital commitment of couples. Journal of Research \& Health, 7(1), 653-662.

Furman, W., Buhrmester, D. Network of Relationships Questionnaire Manual. The University of Denver and the University of Texas at Dallas. Retrieved from http://www.midss.org/sites/default/files/ net-

work_of_relationships_questionnaire_manual.6.21 .2010. doc

Goldberg, L. R. (2010). Personality, Demographics, and Self-Reported Behavioral Acts: The Development of Avocational interest Scales from Estimates of the Amount of Time Spent in Interest-Related Activities. In C. R. Agnew, D. E. Carlston, W. G. Graziano, \& J. R. Kelly (Eds.), Then a miracle occurs: Focusing on behavior in social psychological theory and research (pp. 205-226).
New York: Oxford University Press. Retrieved from http://projects.ori.org/lrg/PDFs_papers/ Goldberg_2010_Avoc_Interests_Chapter.pdf

Stroud, C. B., $\quad$ Durbin, C. E., $\quad$ Saigal, S. D., KnoblochFedders, L. M. (2010). Normal and abnormal personality traits are associated with marital satisfaction for both men and women: An Actor-Partner Interdependence Model analysis. Journal of Research in Personality, 44(4), 466-477.

\section{Галина Бевз}

Доктор психологічних наук, професор, завідувачка лабораторії психології спілкування, Інститут сочіальної та політичної психології Начіональної академії педагогічних наук України, м. Київ (Украӥна)

\section{ПРИЙНЯТТЯ ВЛАСНОЇ ТІЛЕСНОСТІ В КОНТЕКСТІ РОЗВИТКУ ПОДРУЖНІХ ВЗАСМИН: СУПЕРЕЧНОСТI ТА ÏХ УРЕГУЛЮВАННЯ}

\section{Анотація.}

У статті стверджується біопсихосоціальний підхід як такий, що надає можливість охопити різні аспекти психології тілесності у сфері подружньої взаємодії. Результати проведеного дослідження стосуються гендерних відмінностей ставлення до власного тіла у представників подружніх пар, зокрема в категоріях «прийняття-неприйняття» та його презентації у подружній взаємодії через поняття «критика зовнішності 3 боку партнера» та «мотивація до зміни власного тіла». Учасники дослідження - 300 осіб віком від 19 до 75 років. Дослідження проводилося методом безпосереднього та он-лайн анкетуванням. За результатами дослідження, що проводилося на 
території України, було підтверджено антономічну природу тілесності у контексті подружнього життя, статистично доводено, що позитивне ставлення до власного тіла виступає умовою позитивного світосприймання, просоціальності та задоволеності сімейним життям, як загалом, так і щодо кожної його сфери.

Стверджується, що ставлення до власного тіла є ситуативною характеристикою, що є змінною впродовж життя. Встановлено, що, в ситуаціях критики зовнішності з боку партнера, первинно зафіксоване позитивне ставлення до власного тіла зазнає перегляду (аж до його руйнаціі). Доводиться реактивний характер мотивації змін власного тіла: конфліктне, антагоністичне та критикуюче середовище посилює мотивацію до змін власного тіла і $\epsilon$ більш характерно жінкам до 30 років без дітей.

Дослідженням встановлені ефекти відновлення позитивного ставлення до власного тіла. Вони стосуються ситуацій прояву компанійськості та підтримки 3 боку партнера як відповіді на запит; розвитку сфери інтересів, які $є$ соціабельними та перспективно направленими на екологічність щодо опанування життєвим середовищем. Доводиться, що позитивному ставленню щодо власного тіла слугують стосунки взаємопідтримки, інтерес до їжі та побуту тим самим вказуючи на напрямки розбудови культури подружніх взаємин.

Перспективою подальших досліджень видається вивчення природи тілесності як системного утворення і культурного явища, що розкриває подружній потенціал щодо збалансованого функціонування в життєвому середовищі.

Ключові слова: сім'я, подружжя, гендерні стосунки, психологічна культура.

\section{Бевз Галина}

Доктор психологических наук, профессор, заведующая лаборатории психологии общения Института сочиальной и политической психологии Национальной академии педагогических наук Украинь, г. Киев (Украина)

\section{ПРИНЯТИЕ СОБСТВЕННОЙ ТЕЛЕСНОСТИ В КОНТЕКСТЕ РАЗВИТИЯ СУПРУЖЕСКИХ ВЗАИМООТНОШЕНИЙ: ПРОТИВОРЕЧИЯ И ИХ УРЕГУЛИРОВАНИЕ}

Аннотация. В статье утверждается биопсихосоциальной подход как таковой, что позволяет охватить различные аспекты психологии телесности в сфере супружеского взаимодействия. Результаты проведенного исследования касаются гендерных различий отношения к собственному телу у представителей супружеских пар, в частности в категориях «принятие-непринятие» и его презентации в супружеской взаимодействия через понятие «критика внешности со стороны партнера» и «мотивация к изменению собственного тела». Участники исследования - 300 человек в возрасте от 19 до 75 лет. Исследование проводилось методом непосредственного и он-лайн анкетирования. По результатам исследования, 
которое проводилось на территории Украины, было подтверждена антиномичная природа телесности в контексте семейной жизни, статистически доказано, что позитивное отношение к собственному телу выступает условием положительного мировосприятия, просоциальности и удовлетворенности семейной жизнью, как в целом, так и в каждой из её сфер.

Утверждается, что отношение к собственному телу является ситуативной характеристикой, что изменяется с течением жизни. Установлено, что в ситуациях критики внешности со стороны партнера, первично зафиксированное положительное отношение к собственному телу подвергается пересмотру (вплоть до разрушения). Приходится реактивный характер мотивации изменений собственного тела: конфликтное, антагонистическое и критикующая среда усиливает мотивацию к изменениям собственного тела, что более характерно женщинам до 30 лет без детей.

Исследованием установлены эффекты восстановление позитивного отношения к собственному телу. Они касаются ситуаций проявления дружественности и поддержки со стороны партнера как ответа на запрос; развития сферы интересов - социабельных и перспективно направленных на экологическое освоение жизненной средой. Доказывается, что позитивному отношению к собственному телу служат отношения взаимопомощи, интерес к еде и быту тем самым указывая на направления развития культуры супружеских взаимо- отношений.

Перспективой дальнейших исследований представляется изучение природы телесности как системного образования и культурного явления, которое раскрывает супружеской потенциал сбалансированного функционирования в жизненной среде.

Ключевые слова: семья, супруги, гендерные отношения, психологическая культура.

\section{Halyna Bevz}

Phd (Doctor of Psychology), Professor, Head of Communication Psychology Lab, Institute for Social and Political Psychology of National Academy of Educational Sciences of Ukraine, Kyiv (Ukraina)

\section{ACCEPTANCE OF OWN CORPOREALITY IN THE CONTEXT OF THE DEVELOPMENT OF MARITAL RELATIONSHIPS: CONTRADICTIONS AND THEIR RESOLUTION}

\section{Summary}

The article states the biopsychosocial approach as providing an opportunity to cover different aspects of the psychology of corporeality in the sphere of marital interaction. The results of the study relate to the gender differences in the attitude of the married couples to their own body, in particular, in the categories of «acceptancerejection» and its presentation in marital interaction through the concept of «criticism of the appearance of the partner» and «motivation to change one's own body». Participants of the study are300 persons aged from 19 to 75 years old. The research was conducted by the method 
of direct and on-line testing.

According to the results of the research, which was conducted on the territory of Ukraine, the antonymic nature of corporeality in the context of married life was confirmed, and it was statistically proved that positive attitude towards one's own body is a condition of positive perception of the world, prosociality and satisfaction with family life as a whole and with each one of its spheres.

It is stated that the attitude towards one's own body is a situational characteristic that is variable throughout life. It was found that in situations of criticism of the appearance on the part of the partner, the initially fixated positive attitude to one's own body undergoes a revision (up to its destruction). The reactive character of the motivation for changes in one's own body is being proved: conflicting, antagonistic and criticizing environment enhances the motivation to change one's own body and is more characteristic for women under the age of 30 without children.

The research has found the effects of restoring a positive attitude towards one's own body. They relate to situations of manifestations of sociability and support of the partner as a response to a request; development of the sphere of interests that are sociable and promisingly directed for environmentally friendly management of the living environment. It is proved that the positive attitude towards one's own body is based on the relationship of mutual support, interest in food and mode of life, thereby pointing to direc- tions of development of the culture of marital relationships. The prospect of further research is the study of the nature of corporeality as a systemic and cultural phenomenon, which reveals the marital potential of balanced functioning in the living environment.

Key words: family, marriage, gender relationship, physical culture.

Дата отримання статті: 15.06.2019 Дата рекомендації до друку: 25.06.2019 Дата оприлюднення: 29.06.2019 